\title{
RECOVERY OF GOVERNMENT GRATUITIES: DEFENSES OF ESTOPPEL AND NONREVIEWABILITY
}

In recent years dissatisfaction with the favorable position granted the Federal Government in noncriminal litigation has intensified. 1 In the words of Mr. Justice Jackson, "It is very well to say that those who deal with the Government should turn square corners. But there is no reason why the square corners should constitute a one-way street."2 This dissatisfaction has sometimes led courts to escape the harshness of the doctrine that estoppel is not available against the Government by expanding the domain of unreviewable administrative action to deny the Government recovery of erroneously paid gratuities. But use of reviewability doctrines to deny recovery by the Government often distorts the law applicable when private parties rather than the Government seek review. And paradoxically, so blunt a judicial tool will frequently deny the Government recovery of gratuities in cases where a coherent estoppel doctrine would allow recovery.

Three cases illustrate these propositions.

In United States v. Zenith-Godley Co., ${ }^{3}$ the United States sued to recover money paid to handlers for butter by the Commodity Credit Corporation. The payments had been made pursuant to a regulation issued by the Secretary of Agriculture, which allowed support payments to be made without actual delivery of butter to the CCC. A preexisting alternative procedure required delivery of butter to the $\mathrm{CCC}$ which purchased it at a set price and immediately resold it to the handler at a lower price, the differential representing a support payment. Recovery was allowed in spite of the defendant's claim that the Government was estopped by detrimental reliance on the Secretary's regulation, since the alternative procedure might have been used had the regulation not been issued. 4

Stone v. United States 5 is a second case illustrating the injustice that may

1 On the dissatisfaction with applicability of the doctrine of estoppel against the Government, see, e.g., 2 Davis, ADMInIsTrative LaW \$\$ 17.01-17.06 (1958); Berger, Estoppel Against the Government, 21 U. CHI. L. Rev. 680 (1954); Pillsbury, Estoppel Against the Government, 13 Bus. LAw. 508 (1958); The Proper Case for Estoppel Against Federal Administrative Agencies, 28 Notre DAME LAW. 234 (1953).

2 Federal Crop Ins. Corp. v. Merrill, 332 U.S. 380, 387-88 (1947) (dissenting in a 5-to-4 decision).

3295 F.2d 634 (2d Cir. 1961).

${ }^{4}$ The court observed, however, that "it is not demonstrated that the appellants would have been able to deplete their inventories to take advantage of the pre-existing valid procedure." Id. at 635 n.1.

5286 F.2d 56 (8th Cir. 1961). 
result from the lack of estoppel against the Government. There the United States was allowed to recover support payments made to a wool grower on the basis of an error in statutory construction made by a local Government agent acting clearly beyond his authority. The program in question provided for Government payments equal to the difference between support and market price upon the "sale" of wool by growers. The local agent had assured the grower that a transfer of wool to a "wool house" owned by the grower was a "sale" within the meaning of the act. Had the agent properly construed the statute, the grower would, of course, have sold the wool to third parties and would have had his "wool house" buy wool from third parties, thus qualifying for the support payments. ${ }^{6}$

In United States v. Wiley's Cove Ranch, ${ }^{7}$ on the other hand, the Government failed to recover in a case where recovery might reasonably have been thought suitable. The Government sued to recover emergency feed payments made to allow a cattle ranch to maintain its foundation herd. 8 The payments were made on the basis of a recommendation by a County Committee which certified that the ranch in question met the requirement of need imposed by the applicable regulations. 9 No evidence of detrimental reliance by the ranch

6 Id. at 57.

7295 F.2d 436 (8th Cir. 1961).

8 The Emergency Feed Program, 67 Stat. 150 (1953), authorized the Secretary of Agriculture to furnish to farmers, ranchers, and stockmen in disaster areas feed for livestock and seeds for planting. The Secretary transferred to the Farmers' Home Administration the function of providing eligibility rules, and to the County Committees set up by that agency the function of certifying applicants. 19 Fed. Reg. 4674 (1954).

9 The opinion discloses that some question had arisen as to the eligibility of the defendantranch and reveals that an undisclosed party had requested that the ranch's eligibility be recertified. Recertification was granted before the defendant received the feed. 295 F.2d at 438-39.

Subsequent to receipt of the assistance by the defendant, the State Director of the Farmers' Home Administration informed him by letter that his application had been rejected by the "National Office" and demanded reimbursement. Id. at 437 .

Further confusion would have resulted if the Government had contended that the determination of the superior officers was conclusive as to impropriety in a suit for recovery. Cases involving the Veterans' Administration illustrate the issues which would then arise. By statute the decisions of the Veterans' Administration are made final and not reviewable. Some courts have held that a determination by the VA that a given payment was improper is conclusive in a suit for recovery by the United States. United States v. Rhode, 189 F. Supp. 842 (D.S.D. 1960); United States v. Crockett, 158 F. Supp. 460 (D. Me. 1958); United States v. Perry, 141 F. Supp. 443 (E.D.N.C. 1956); United States v. Gudewicz, 45 F. Supp. 787 (E.D.N.Y. 1942) (semble). Contra, United States v. Lawrence, 154 F. Supp. 454 (D. Mont. 1957); United States v. Owens, 147 F. Supp. 309 (E.D. Ark. 1957). The determination, however, must contain findings sufficient to support the result in order to be conclusive. United States v. Gibson, 207 F.2d 161 (9th Cir. 1954). These post-payment determinations, however, were reached only after notice to the recipient of the reconsideration and a hearing to determine the possibile impropriety. To hold the FHA's determination to be conclusive in Wiley's Cove would certainly raise problems of fairness, if not of due process. The Supreme Court in United States v. New York, N.H. \& H. R.R., 355 U.S. 253 (1957), a case involving payments to railroads declared to have been erroneous by the General Accounting 
appeared in the opinions of the district and circuit courts. Nevertheless, the courts manipulated reviewability doctrine to bar the Government's recovery on the ground that the certification of the County Committee was final.

The thesis of this comment is that the court in Wiley's Cove Ranch erred in holding that the County Committee's actions barred the Government's suit. The existence of a coherent estoppel doctrine would have allowed Wiley's Cove to turn on whether detrimental reliance on the Government action had been shown (assuming the payment to have been erroneously made), and would not have allowed recovery in the Zenith-Godley and Stone cases.

\section{The Right of the Government To Recover Erroneous Payments}

The right of the United States Government to recover payments erroneously made under a mistake of law or fact was established at an early date.10 Numerous cases have reaffirmed the right.11 A qualification to this rule is that of Butte, A. \& Pac. Ry. v. United States. 12

In Butte, the Government sued to recover payments made to a railroad for

Office without notice or hearing, stated that "We do not here intimate that the administrative determination of overpayment has binding effect in the judicial proceeding. ..." Id. at 264. However, the Court has not otherwise considered the problem .

The application of the above principle to grant recovery, however, may be inapposite in the Wiley's Cove situation. There the statute did not declare that the actions of the Secretary of Agriculture were not subject to review. Nor has it been clearly established that the discretion granted the Secretary is sufficiently great to bar review of his determinations at the request of the defendant-recipient in a suit for recovery, although this would probably be the case if the alternative standards of the Administrative Procedure Act as to reviewability, 60 Stat. 243 (1946), 5 U.S.C. $\$ 1009$ (1958), are to be followed. See text accompanying note 21 infra. Perhaps in this area, however, courts will confine the doctrine of the legal conclusiveness of an administrative determination because of possible harsh results and limit its application to cases where statutes explicitly preclude review.

10 United States v. Bank of the Metropolis, 40 U.S. (15 Pet.) 377, 399-400 (1841), is the leading case.

11 United States v. Wurts, 303 U.S. 414 (1938) (tax refund); Wisconsin Cent. R.R. v. United States, 164 U.S. 190 (1896) (payments to land grant railroads for carrying mail); United States v. Sanborn, 135 U.S. 271 (1890) (payments to self-employed tax collector erroneously believed to have performed substantial services); United States v. Burchard, 125 U.S. 176 (1888) (military retirement pay); Kingman Water Co. v. United States, 253 F.2d 588 (9th Cir. 1958) (payment for water to public utility in excess of rates allowed by state commission); United States v. Rhode, 189 F. Supp. 842 (D.S.D. 1960); United States v. Daubendiek, 25 F.R.D. 50 (N.D. Iowa 1959) (veteran's benefits paid on basis that defendant was fully engaged in on-the-farm institutional training); United States v. Crockett, $158 \mathrm{~F}$. Supp. 460 (D. Me. 1958) (veteran's benefits paid on basis that defendant was self-employed); United States v. Perry, 141 F. Supp. 443 (E.D.N.C. 1956) (veteran's benefits paid on basis that defendant was fully engaged in farming and had no income); United States v. Gudewicz, 45 F. Supp. 787 (E.D.N.Y. 1942) (veteran's benefits paid a person eventually discharged because of Russian citizenship); $c f$. United States v. Bentley, 107 F.2d 382 (2d Cir. 1939) (veteran's benefits paid on basis that provisionally commissioned officer was eligible). But cf. Badeau v. United States, 130 U.S. 439 (1889) (military retirement pay).

12290 U.S. 127 (1933). 
"deficits" incurred during the First World War. The payments had been made pursuant to a construction of the word "deficit" by the Interstate Commerce Commission which had been repudiated by the Commission after a change in membership. ${ }^{13}$ Prior to the Government's suit for recovery portions of the reimbursement had been distributed by the railroad as dividends to its shareholders. The Court held the rule allowing the Government to recover monies paid by mistake inapplicable.14 According to Mr. Justice Brandeis the suit involved:

[A] charge, not of mistake, but of error of judgment. . . [ [U]nder section 204 the Commission exercises functions broader than those customarily conferred upon auditing or disbursing officers. It acts as a special tribunal to hear and determine the claims presented. ... It renders a judgment upon a full hearing. In deciding any one of the enumerated questions of construction, the Commission may err. The victim of the error may be either the carrier or the Government. ... Since authority to pass upon the meaning of the word "deficit," and upon each of the other questions of construction, is essential to the performance of the duty imposed upon the Commission, and Congress did not provide a method of review, we hold that it intended to leave the Government, as well as the carrier, remediless whether the error be one of fact or of law. 15

It is not clear whether the Butte case may still operate as a significant limitation on the Government's right to recover monies paid by mistake. The case has been read as predicated upon the particular wording of the statute there involved.16 Its result may flow from a view that though in form the

13 The specific question of statutory construction involved two very difficult alternatives. Section 204 used the word "deficit" fourteen times, but only once in paragraph (a). 60 Stat. 460-61 (1920). To construe it in favor of the railroad would require attributing to the word as used in paragraph (a) a meaning inconsistent with the usage in the other paragraphs, at a cost to the Government approximating three million dollars because 70 other carriers were involved. ICC ANN. REP. 13-14 (1928). For the court to affirm a judgment based on the second ICC decision would have led, according to the first ICC decision, "to results which are so inequitable as to be absurd." In the matter of the construction of the word "Deficit" as used in paragraph (a) of Section 204 of the Transportation Act, 1920, 66 I.C.C. 765, 772 (1922); Note, 43 YALE L.J. 503, 505 (1934).

14290 U.S. at 143.

15 Id. at 134, 142-43. (Emphasis added.)

16 "Congress prescribed the command. Like the command in the Butte Ry. case, it contained no exception. Here, as in that case, the intent seems plain-the dispute was to reach its last terminal point when the administrative finding was made. There was to be no dragging out of the controversy into other tribunals of law." Switchmen's Union v. National Mediation Board, 320 U.S. 297 (1943). In a letter to the Chairman of the Senate Judiciary Committee concerning Section 10 of the Administrative Procedure Act, 60 Stat. 243 (1946), 5 U.S.C. $\$ 1009$ (1958), as it now stands, the Attorney General stated: "This section, in general, declares the existing law concerning judicial review. It provides for judicial review except insofar as statutes preclude it, or insofar as agency action is by law committed to agency discretion. A statute may in terms preclude judicial review or be interpreted as manifesting a congressional intention to preclude judicial review. Examples of such interpretation are: .. . Butte, Anaconda \& Pacific Railway Co. v. United States (290 U.S. 127.)" LeGISlative History of the Administrative Procedure Acr 229-30 (1946). 
Commission merely passed on the award of a gratuity, in fact, it "act[ed] in a quasi-judicial capacity, in many respects similar to the Court of Claims, [and] its attempts to reopen settlements and to apply its new rulings retroactively will be analogous to a law courts' changing a judgment after the close of its term and after the judgment has been satisfied."17 The decision may also have been based on a feeling of a part of the Court that to allow the Government to recover would have appeared inconsistent with the Court's recently expanded reluctance to allow private parties to seek judicial aid in cases where the ICC found no basis for exercising its authority on their behalf.18

Whatever the present status of a case that may be read as limited to "errors of judgment" in quasi-judicial adversary proceedings before agencies like the ICC might be, it is entirely clear that as to ordinary mistakes the Government can recover. To bind the Government by the mistakes of fact of a disbursing agency would in most cases be an undesirable result. Speed in payment is generally desirable and hence recovery as a result of post-transaction review is a necessity. 19 This may be especially true in cases of emergency assistance such as Wiley's Cove Ranch. The court in Butte recognizes this as to mistakes by mere auditing or disbursing officers, and this rule should apply whether the disbursement is made by a subordinate agency, as in Wiley's Cove, or by an agency in which discretionary as well as disbursing powers have been vested by statute.

17 Note, 43 YaLe L.J. 503, 504 (1934). In Wyandotte Terminal R.R. v. United States, 64 Ct. Cl. 329 (1927), cert. denied, 276 U.S. 630 (1928), it was held that the statutory provision giving the ICC authority to reimburse deficits resulting from wartime competition with Government-operated railroads operated to oust the Court of Claims of jurisdiction over damage claims.

In summarizing the law relating to recovery of erroneous payments by the Government, Note, American Economic Mobilization, 55 HARv. L. REv. 427, 509 n.506 (1942), took note of Butte in observing "if . . . payment by the Government did not follow a determination judicial in its nature it could be recovered on the basis of the rule that protects the sovereign against payments made under a mistake of law." Accord, Note, 54 HARv. L. REv. 1248, 1249 (1941); see also United States v. Bentley, 107 F.2d 382 (2nd Cir. 1939), discussed in text at note 29 infra.

18 In Bikle, Mr. Justice Brandeis and the Regulation of Railroads, 45 HARv. L. REv. 4, 15 (1931), it was noted that "it is not without significance that where difference of opinion arises as between different members of the Court the tendency of Mr. Justice Brandeis seems to be to support the [Interstate Commerce] Commission." That commentator also discussed the development of "the rule . . . that, where the Commission, taking jurisdiction, finds no basis for exerting its authority, the courts are without jurisdiction to pass on the propriety of its decision." It was noted that "several important decisions in which the opinions have been rendered by Mr. Justice Brandeis, outline hopefully the significance of this proposition. Chicago Junction Case, 264 U.S. 258 (1924); Great Northern Ry. v. United States, 277 U.S. 172 (1928); Piedmont \& Northern Ry. v. United States, 280 U.S. 469 (1930). . . . [F]urthermore, it is an opinion of Mr. Justice Brandeis that established the necessity for a legal interest in order to contest the validity of Commission action, Edward Hines Trustees v. United States, 263 U.S. 143 (1923)." Id. at 15 n.39.

${ }^{19}$ Cf. United States v. New York, N.H. \& H. R.R., 355 U.S. 253 (1957). 
The court in Wiley's Cove Ranch relied on Section 10 of the Administrative Procedure Act, 20 which governs reviewability of agency determinations, in barring judicial inquiry into the propriety of the decision of the County Committee. The court was in error in its use of this provision. The section limiting review states that:

Except so far as (1) statutes preclude judicial review or (2) agency action is by law committed to agency discretion,

(a) Any person suffering legal wrong because of any agency action ... shall be entitled to judicial review thereof.21

The word "person" is defined so as to exclude Government agencies.22 Therefore the "except" clause of section 10 does not apply to them. The right of Government agencies to judicial review by means of an action to recover a mistaken payment under the doctrine of United States v. Bank of the Metropo$l_{i s^{23}}$ as modified by Butte is not affected by Section 10 of the Administrative Procedure Act.

The only other possible basis of the Wiley's Cove decision would be supplied by that reading of the Butte case which focuses not on reviewability but on the quasi-judicial nature of the agency determination. 24 This reading invokes principles akin to res judicata, 25 to prevent the agency from reopening matters already decided.

The court in Wiley's Cove erred in comparing the determination by the County Committee, a subordinate body, to the first decision of the ICC in Butte. Power to administer the program involved in Wiley's Cove rested in the hands of the Farmers' Home Administration national office, not in the hands of the County Committee.26 The court in Wiley's Cove concluded, however, that the national office foreclosed the possibility of construing its own regulations by failing to provide in the regulations for review of the committee de-

2060 Stat. 243 (1940), 5 U.S.C. $\S 1009$ (1958).

21 Ibid.

2260 Stat. 243 (1946), 5 U.S.C. $\$ 1001($ b) (1958) states: “ 'Person' includes individuals, partnerships, corporations, associations, or public or private organizations of any character other than agencies." For a discussion of this aspect of the decision see, Comment, Judicial Review of Federal Administrative Decisions Concerning Gratuities, 49 VA. L. REv. 313, 335-36 (1963).

23 See note 10 supra.

${ }^{24}$ This interpretation is possible, but not plausible, since the court's explicit holding in Wiley's Cove was stated in reviewability terms. 295 F.2d at 446.

25 See text accompanying note 17 supra.

${ }^{26}$ See note 8 supra; 19 Fed. Reg. $74 \S 116$ (1954): "[T]he head of any agency is hereby delegated authority to take any action, including the authority to execute any document, authorize any expenditure, and promulgate any rule, regulation, order or instruction, required by him to be necessary and proper to the discharge of the functions assigned to his agency." 
terminations. 27 However, it would seem plain that the Farmers' Home Administration could exercise such a power. Since the lack of a regularized procedure for doing so flowed merely from its own practice, not from a statutory mandate, any other result would allow a subdelegate to greatly impair the power of the Farmers' Home Administration. To allow local committees to haphazardly construe the regulations of the administering agency can result in much confusion, and possibly in inequitable results based on "the length of the committeeman's foot."28 Indeed, even if the statute had in terms expressly vested final power in the County Committees alone, making no mention of the Secretary of Agriculture or the Farmers' Home Administration, the determinations of the County Committees still would not be the kind of determinations which fall within the narrow exception to Government recovery delineated in Butte.

The narrowness of the Butte exception is well brought out in United States v. Bentley. ${ }^{29}$ There the Government sued to recover part of the payments made to a former National Guardsman on his veterans' adjusted service certificates. In spite of the fact that payment had originally been certified by the Secretary of War, whose decisions were declared by statute to be "final and conclusive"; that official was allowed to alter his original decision and seek recovery. The court declared that no reviewability question was presented since the statute "was not designed to prevent review of their own decisions by the officials themselves, but to limit any review of the courts." 30 The court distinguished Butte by saying that:

27295 F.2d at 445. "Had it been so intended, a clause [providing for review] could have been put into the regulations, as was subsequently done, in dealing with the granting of farm loans by the Farmer's Home Administration." Ibid. In 1959 the Farmers' Home Administration regulations for assistance payments were revised to provide for review by the State Director with proper notice and a hearing given the applicant. 6 C.F.R. $\$ 475.155$ (4) (Supp. 1962).

However, the regulations of the Farmers' Home Administration relating to its loan functions applicable at the time of the assistance to Wiley's Cove Ranch provided for review only in the case of Water Facilities Loans, the review to be exercised by the approval official. Other loan programs provided only for approval of the loan by some intermediate official after initial certification by the County Committee. Farm Ownership Loans, 13 Fed. Reg. 9411 $\$ 331.4,9413$ \$ 332.4 (1948); Production and Subsistence Loans, 17 Fed. Reg. 7801 \$ 341.2, 341.3 (1952); Water Facilities Loans, 17 Fed. Reg. $7807 \$ \$ 351.1,351.2$ (1952); 17 Fed. Reg. 8568 352.8(a) (1952). It would appear that the national office was inconsistent in providing for divided responsibility for the grant of loans to be repaid, while not doing so for gratuities.

28 One commentator, however, has commended the infusion of local wisdom into the administrative process in this form by observing that: "The use by the United States Department of Agriculture of county committees ... in working out the local application of the national policies,' has been commended; and the Department's largely successful 'effort to democratize the administration' of the various land use programs has been called 'one of the most significant developments in public administration.'" GellhorN, Federal ADministrative Proceedings 126 (1941).

29107 F.2d 382 (2d Cir. 1939).

$30 \mathrm{Id}$. at 383 . 
the Commission [in Butte] had been constituted a "quasi-judicial tribunal to adjudicate claims" arising under the section ... and ... exercised "functions broader than those customarily conferred upon auditing or disbursing officers," sitting, as it did, "as a special tribunal to hear and determine claims presented," and rendering "a judgment upon a full hearing...." Certainly there is no parallel between the actions of the Commission in specific litigations of that kind and that of the Secretary of War ... in passing upon hundreds of thousands of claims in a necessarily summary way upon their own records. . . . [N]umerous mistakes are inevitable and it is inconceivable that anyone should have wished them to be indelible. ${ }^{31}$

There can be little doubt, in the light of this formulation, that the Government would have a right to recovery in Zenith-Godley, where a superior official overruled himself, as well as in Wiley's Cove and Stone where subordinates were overruled by superiors.

\section{ESTOPPEL AGAINST THE GOVERNMENT}

As the three cases which have been considered suggest, familiar doctrines severely limit estoppel against the Government. Thus, some courts have taken the position that the United States cannot be estopped when acting in a governmental, as opposed to proprietary, capacity. 32 The allowance of estoppel as to "proprietary" activities derives from the feeling that in ordinary business transactions the sovereign should be treated equally with other litigants, 33 regardless of possible difficulties in drawing a proprietary-governmental distinction. Mr. Justice Frankfurter, however, in the leading case of Federal Crop Ins. Corp. v. Merrill, ${ }^{34}$ rejected the distinction, and denied application of estoppel against the Government. Although the Government crop insurance program involved in that case was clearly a proprietary function, a claim by an insured farmer against the Federal Crop Insurance Corporation predicated

31 Id. at 384.

32 Governmental: United States v. City and County of San Francisco, 112 F. Supp. 451, 454 (N.D. Cal. 1953), aff'd, 223 F.2d 737 (9th Cir. 1955); Elrod Slug Casting Mach. Co. v. O'Malley, 57 F. Supp. 915, 920 (D. Neb. 1944). Proprietary: Branch Banking and Trust Co. v. United States, 98 F. Supp. 757, 766, 768 (Ct. Cl. 1951); Ohio Oil Co. v. United States, 65 F. Supp. 991, 997 (D. Wyo. 1946), rev'd, 163 F.2d 633, 641 (10th Cir. 1947).

33 " [I]t is hard to see why the ideas of fairness should differ when one of the parties happens to be a governmental unit, especially when the subject matter relates to property or business dealings and not to the process of carrying out government policies. Probably sound reasons do not exist; probably the best reason for holding a governmental unit exempt from equitable estoppel in its business dealings is simply the historical reason that the king can do no wrong. As time goes on, and as the doctrine of sovereign immunity is further eroded, one may expect that the proportion of holdings that a governmental unit may be estopped will continue to increase." 2 DaVIS, ADMINISTRATrve Law 541 (1958); see also, Berger, Estoppel Against the Government, 21 U. CHI. L. Rev. 680, 683-84 (1954).

34332 U.S. 380 (1947) (5-to-4 decision). 
on the basis that misleading statements by the Government's agent estopped it from denying recovery on a policy was rejected:35

And so we assume that recovery could be had against a private insurance company. But the Corporation is not a private insurance company. It is too late in the day to urge that the Government is just another private litigant ... whenever it takes over a business theretofore conducted by private enterprise or engages in competition with private ventures. Government is not partly public or partly private, depending on the governmental pedigree of the type of a particular activity or the manner in which the Government conducts it.... Whatever the form in which the Government functions, anyone entering into an agreement with the Government takes the risk of having accurately ascertained that he who purports to act for the Government stays within the bounds of his authority. ${ }^{36}$

The court in Zenith-Godley properly rejected an effort to distinguish Merrill on the thin basis that no detrimental reliance had been shown in the earlier case. ${ }^{37}$ The court in Zenith-Godley made clear that Merrill "was based not upon the absence of reliance, but upon the ground that the Government is not bound by the unauthorized acts of its agent, even if within the scope of the

35 The refusal of the court in Merrill to allow estoppel against the Government even in respect to proprietary activities seems especially difficult to justify. For sovereign immunity - the underlying basis of the Merrill doctrine-has long been held not to extend to Government corporations. See Keifer \& Keifer v. RFC, 306 U.S. 375 (1939); Bank of United States v. Planters' Bank, 22 U.S. ( 9 Wheat.) 904, 907 (1824) (Marshall, C. J.): "It is, we think, a sound principle, that when a government becomes a partner in any trading company, it devests [sic] itself, so far as concerns the transactions of that company, of its sovereign character, and takes that of a private citizen. Instead of communicating to the company its privileges and its prerogatives, it descends to a level with those with whom it associates itself, and takes the character which belongs to its associates, and to the business which is to be transacted .... The State, ... by giving to the Bank the capacity to sue and be sued, voluntarily strips itself of its sovereign character, so far as respects the transactions of the Bank, and waives all the privileges of that character." The opinion in Merrill does not mention the Planters' Bank case, and did not undertake to distinguish Keifer. Justice Frankfurter, who wrote for the Court in both Keifer and Merrill, apparently accepted the Government's contention that Keifer "at the most, . . . stands for the proposition that where federal governmental corporations are concerned, a waiver of immunity to suit should be liberally construed." Brief for Petitioner, p. 25, n.11, Federal Crop Ins. Corp. v. Merrill, 332 U.S. 380 (1947).

36332 U.S. at $383-84$.

37 United States v. Zenith Godley Co., 295 F.2d 634, 635 (2d Cir. 1961). The Supreme Court of Idaho had stated in its opinion that "the ultimate question in this case is not one of constructive notice but of equitable estoppel. Under the facts in this case all of the elements of equitable estoppel are present." Merrill v. Federal Crop Ins. Corp., 67 Idaho 196, 199, 174 P.2d 834 (1946). Since detrimental reliance is an element of equitable estoppel, the contention of the defendant in Zenith-Godley was erroneous.

However, when the facts of Merrill are also considered, it is not so clear that the farmers suffered detriment from reliance. The application and misrepresentation were made on March 25, 1945, but the indications are that the applicants had commenced planting the crop prior to that date. Brief for Respondent, pp. 3-4. Furthermore, crop insurance was not available elsewhere. 
agent's apparent authority." 38 And, of course, the fact that the representation in Zenith-Godley was made by the Secretary of Agriculture rather than by a local agent or a local committee could make no difference; the Secretary could not be allowed to make an unauthorized rule effective against the world by way of estoppel, however great his discretion as to other matters might be, given the Merrill emphasis on the actual authority of the agent.

In the light of Merrill, the decision in Stone is not surprising. There the Eighth Circuit rejected a plea of estoppel based on representations as to the meaning of the statute by a local agent who clearly acted beyond his authority. Stone does suggest that the defendant in Wiley's Cove could not have successfully invoked an estoppel theory, even though in Wiley's Cove it is unclear whether the County Committee's original certification was in fact erroneous. 39

The fact that the Government was allowed to recover in Zenith-Godley and in Stone is indicative of the injustices which flow from the doctrine that there can be no estoppel against the Government. Wiley's Cove is also a case in which it would be reasonable to allow the defense of estoppel should the facts indicate detrimental reliance.40 It is true that in Wiley's Cove, unlike the other two cases, it is not clear from the opinion that any detriment was suffered as a result of the allegedly unauthorized action by Government officials. ${ }^{41}$ The

38295 F.2d at 635 .

${ }^{39}$ In Stone, like Merrill, it was clear that the local agent had exceeded his authority. Stone v. United States, 286 F.2d 56, 57 (8th Cir. 1961) "These purported sales do not, of course, constitute sales within the meaning of the Wool Act and regulations ... nor does the defendant so contend."

${ }^{40} \mathrm{In}$ denying conclusiveness in a suit for recovery to a VA determination of improper payment the court in United States v. Owens, 147 F. Supp. 309 (E.D. Ark. 1957), see note 9 supra, took the view that "the manifestly harsh results that would flow from the interpretation of Section 705 that is urged by the plaintiff would seem to be contrary to the beneficent intent of Congress ... and, indeed, might make the receipt of benefits under such a program a delusion and a snare, particularly when it is realized that the defenses of limitations, laches, and estoppel, usually available in controversies between man and man, cannot, ordinarily, be successfully urged against the Government." 147 F. Supp. at 314.

41 The subsequent case of United States v. Robbins, 207 F. Supp. 799 (D. Kan. 1962), involving another suit by the Government for recovery of assistance under the Emergency Feed Program, may be indicative of the manner in which the program was administered at the County Committee level and of the consequent difficulty of showing the detrimenta1 reliance on which an estoppel must be based. There the court made relatively clear the financial position of the applicant. "The balance sheet ... showed a total value of over a million and a half dollars in 1951. [It is not clear whether the court is referring to total assets or to net worth.] This was reduced by 1956 to $\$ 868,073.56$. The statement of income of the Robbins Ranch disclosed a net operating loss of over $\$ 32,000$ in 1950 and up to $\$ 160,546.09$ in 1956. The only year in which there was a net operating income was 1951 and the income was $\$ 154,720.10$. These losses were overcome by virtue of the sale of replacement breeding animals and breeding animals sold because of drought conditions. The net income ... during the period of 1950 to 1956 was in excess of a million and a half dollars. To obtain this income the Robbins Ranch had sold in excess of six thousand head of their breeding herd for a price of three and one-third million dollars." Id. at 801 . The aid in question totaled $\$ 4,273.35$. 
opinion does not establish that the foundation herd would not have been maintained but for the Government payments, nor does it suggest that there was any other sort of detrimental reliance. However, if the ranch could show that it suffered loss from a dangerous reduction in its cash position in reliance upon the propriety of Government assistance, substantial support would be provided for a finding of detrimental reliance, quite apart from any change in policy as to maintenance of the foundation herd. 42

Thus, it would seem that Wiley's Cove as well as Zenith-Godley and Stone would supply an appropriate case for estoppel against the Government. This conclusion is reinforced by the long delay prior to the Government's institution of suit for repayment.43 Although this conclusion as to desirable law may explain, it cannot excuse, the court's misuse of the Butte doctrine to deny the Government recovery in Wiley's Cove.

\section{ConClusion}

It is desirable that present doctrines denying estoppel against the Government be modified just as it is desirable that the sovereign immunity doctrines that are the source of present estoppel rules be changed. A coherent estoppel doctrine would continue to bar estoppel in some situations, just as a coherent immunity doctrine would continue to bar some suits against the Government, especially those based on legislative and judicial functions. 44 Principles developed in one sphere should prove relevant in the other; at a time when sovereign immunity is increasingly in disfavor there can be little excuse for continuing to bar estoppel.45 The two doctrines are intimately related, and it

42 See note 37 supra.

43295 F.2d at 446 (5-year delay).

443 Davis, Administrative LAw $\$ \$ 25.15,25.16$ (1958), rejects the notion that: "[G]overnmental units should be liable for all private losses they cause. Most such losses, as now, will have to be regarded as part of the necessary price for the benefits of living in organized society. Nearly all policy determination-legislative, executive, judicial, or administrativehurts someone. The losses caused by policy choices are usually well spread, and even when they are not, as when a statute destroys a profitable business by prohibiting sale of a product deemed harmful, the governmental unit probably should be immune from liability." $3 \mathrm{id}$. $\$ 25.17$.

45 But $c f$. Stone v. United States, 286 F.2d 56 (8th Cir. 1961), where the court, in establishing an atmosphere suitable for a rejection of the estoppel defense, quoted RFC Y. Tuolumne Gold Dredging Corp., 137 F. Supp. 855, 857 (N.D. Cal. 1953). "Courts administer justice not alms .... Fortunately, however, we have a Supreme Court that is steadily moving away from this eleemosynary philosophy of Government." Tuolumne cited Federal Crop Ins. Corp. v. Merrill, 332 U.S. 380 (1947), as authority for this assertion. The Tuolumne case held that the lien of a dredging corporation did not have priority over that of the RFC.

In a different context - the denial of judicial review of agency actions declining to award Government gratuities-Professor Jaffe has noted that: "As government takes more and more services and amenities, and for their support takes a larger and larger part of the citizen's dollar, it is both absurd and dangerous to look upon these services as "privileges." " Jaffe, The Right to Judicial Review II, 71 HaRv. L, REv. 769, 784 (1958). 
is paradoxical that in present federal law denial of estoppel persists in areas where sovereign immunity has broken down. 46

Until coherent estoppel doctrines are developed injustice to both the Government and private parties will continue. The Government will be prejudiced when courts manipulate the Butte doctrine in the furtherance of unspecified private equities-as in Wiley's Cove-and deny recovery in cases where a coherent estoppel doctrine would allow recovery. Contrariwise, this manipulation of the Butte doctrine may operate to permit recovery-as in ZenithGodley and Stone-where it would be denied by an explicit and coherent doctrine of estoppel.

46 See note 35 supra. 